\title{
Ecological Damage Compensation for Coastal Sea Area Uses
}

\author{
Huanhuan Rao ${ }^{\mathrm{a}}$, Chenchen Lin ${ }^{\mathrm{a}}$, Hao Kong ${ }^{\mathrm{a}}$, Di Jin ${ }^{\mathrm{b}}$, Benrong Peng ${ }^{\mathrm{a}^{*}}$ \\ ${ }^{\mathrm{a}}$ Joint Key Laboratory of Coastal Study, Coastal and Ocean Management Institute, \\ Environmental Science Research Center, \\ Xiamen University, Xiamen, Fujian 361005, China \\ ${ }^{\mathrm{b}}$ Marine Policy Center
}

*Corresponding author. Email address:brpeng@xmu.edu.cn

Woods Hole Oceanographic Institution

Woods Hole, MA 02543, USA

9

20




\section{Abstract}

Rapid economic growth has resulted in significant ecological degradation in many coastal areas in China. Control measures involving Marine Ecological Damage Compensation (MEDC) have been introduced to curb unsustainable development. The study presents a practical framework for developing the MEDC standard. The standard considers spatial variation in ecological services and includes many different types of ocean uses that are common in coastal waters around the world.We illustrate the framework and specific procedures through a case study of Xiamen.Results of our calculation show that damages from many ocean uses to the ecosystems are not adequately compensatedunder current management regime, and a carefully designed MEDC standard is crucial for sustainable development.

Keywords:Ecological damage, ecosystem evaluation, compensation,sea areause, Xiamen 


\section{Introduction}

Rapiddevelopment of marine industries and the coastal economy in China has resulted in the deterioration of coastal ecosystems and the environment (CCICED,2012; Peng et al., 2009).Apart fromdirect economic values, such as seafood production, the coastal and marine ecosystems provide various other services to the society, such as nutrient recycling, shoreline protection, and climate regulation (de Groot et al., 2002). These services are vital for human survival andwellbeing. Unsustainable coastal development is diminishing the capability of marine ecosystems to provide the services. To ensure sustainable development in China's coastal regions, government agencies, such as the State Oceanic Administration (SOA), have introduced market-based control measures involvingMarine Ecological Damage Compensation (MEDC). The basic idea is tomakedevelopers of ocean space pay the full costs associated with their activities, including damages to the marine ecosystems(SOA, 2009). Without MEDC, ocean users only pay private costs (e.g., construction and operating costs), the ecological compensation mechanism is designed to internalize the externalities of different ocean usesso that excessive development activities can be curbed (CCICED, 2007). The collected compensation payments can be used to restore damaged marine ecosystems, as determined by local governments.

There isa substantial literature on the assessment of and compensationfor ecological damages. Most of thestudies focus on the ecological damages associatedwith accidental spills of oil or other hazardous substances or waste disposals (Ryan, 1994; NOAA, 1997; Mason, 2003; Kim, 2003; McCay et al., 2006). Anotherset of studies examines the ecological damages related to coastal reclamation or wetland drainage in China (Wang et al., 2010a, 2010b; Peng et al., 2011) and around the world (Cendrero et al., 1981 ; De Mulder,1994; Hoeksema, 2007; Airoldi and Beck, 2007; Halpern et al., 2008; Elliott,2004;FAO,1999; OSPAR,2008). In contrast, little attention has been paid to the ecological damagesrelated tocoastal development and ocean use activities that are consider regular or routine, such as 
aquaculture, sea bridges, and anchorage.

Although regular ocean space usesneed the approval fromrelevant government agencies in China, under current management system, ecological damages associated with these uses, especially at small scales, are often excluded from compensation considerations. However, these damages are typically long lasting and have considerable cumulative effects on marine habitats and the environment ${ }^{1}$.Under these circumstances, there are continuous and uncompensated losses to the marine ecosystems due to these "regular" uses. Thus, it is urgently needed to establish of aMEDC system that covers a wide range of ocean uses and is easy for coastal managers to implement.

In this paper, we describe a framework for the development of a MEDC standardwith an application to Xiamen.The study area and general method to calculate the values of MEDC are described in Sections 2 and 3, respectively. Estimation procedures are detailed in Section 4. Results are summarized in Section 5. Discussions and conclusions are presented in Sections6 and 7.

\section{Study area}

Located on the southeastern coast of China's Fujian Province, to the west of Taiwan Strait, Xiamen covers a land area of $1,565 \mathrm{~km}^{2}$ and a sea area of $390 \mathrm{~km}^{2}$ with a coastline of $234 \mathrm{~km}$. Xiamen's economy and its well-being depend heavily on its surrounding seas for natural resources, goods and services. Rapidgrowth of local economy, population and urbanization in past decades has resulted in more diversified and intensified utilization of ocean space and resources, which significantly altered the coastal environment. Marine pollution continues to increase. The frequency, geographic coverage, and duration of harmful algae blooms (red tide) have significantly increased since 2000 (Cai, 2008). In addition, large-scale coastal reclamation has destroyed natural habitats of various living resources. These changes

\footnotetext{
${ }^{1}$ Marine aquaculture affectsthe marine ecosystem through biological, chemical, and organic pollutions, habitat modification, as well as wild-caught fish as feed ingredients (Goldburg et al. 2001). Coastal recreation and tourism may cause physical alteration or destruction of habitats (UNEP 2002). The anchors of recreational boats can cause damages to marine habitats (Lloret et al. 2008).
} 
together with over fishing and illegal fishing have led to collapses of many fisheries (Figure 1).

In order to protect its marine environment and ecosystems, the Xiamen People's Congress promulgatedSeveral Regulations of Marine Environmental Protection in 2010, which called for the implementation of a compensation regime for marine ecological damages resulted from sea area uses.

\section{Methods}

Since different sea areas may have different ecosystems that provide different ecosystem services, and the severity of damages to the marine ecosystems also vary by the types of ocean uses, our framework to develop the ecological compensation standard for a coastal region involves five steps (Figure 2). First, the study area is divided into eco-zones according to natural conditions, key habitats, natural resources, unique ecological components (e.g., endangeredand threatened species), and management tradition (e.g., protected areas). Next, specific ecosystem services that each eco-zone provides are identified. The ecosystem service values are then estimated at the unit level for each zone. Also, the level of damages to each ecosystem service is assessed for different types of ocean uses by a panel of experts. Finally, the MEDC standard is developed as follows.

The annual ecological damage $(E D)$ for a specific use in an eco-zone is calculated as:

$$
E D_{i k}=\sum_{j=1}^{j=J} v_{i j} d_{k j}
$$

wherei $(=1,2, \ldots, I)$ is the index for eco-zones; $j(=1,2, \ldots, J)$ is the index for ecosystem services; $k(=1,2, \ldots, K)$ denotes each specific ocean use; $v_{i j}$ stands for the annual value of service $j$ provided by an unit area in zone $i$; and $d_{k j}$ is an adjustment factor representingthe severityof damage to ecosystem service jof ocean use $k$.

For a long-term use of a sea area (e.g., a bridge or a fixed structure), a lump-sum payment for the ecological damage, $E D^{L S}$, can be calculated as: 


$$
E D_{i k}^{L S}=E D_{i k} \frac{(1+r)^{n}-1}{(1+r)^{n} r}
$$

where $r$ is the social discount rate $^{2}$; and $n$ is the number of years.For a permanent loss of ecosystem services, such as in the case of coastal reclamation, the ecological damage can be computed as $E D / r$.

\section{Estimation}

\subsection{Division of Sea Areas}

As mentioned above, different sea areas have differentecosystems and natural resources. In order to reflect these differences, we divide Xiamen's coastal watersinto six management areas, Western Sea, Jiulong River Estuary, Southern Sea, Eastern Sea, Tongan Bay and Dadeng Sea, according to local marine function zoning scheme and management traditions. Inthe six management areas, a total of 27eco-zones are identified according to marine ecological and resource features (Figure3).Note that Figure 3 shows only the primary ecosystem in each eco-zone, and there may be multiple ecosystem types in a specific zone.

\subsection{Identification of Ecosys tem Services}

Peng et al. (2006) developed aclassification of ecosystems in the Xiamen sea areas (Table 1). The ecosystems in each of the 27 eco-zones are first identified according to this classification, as shown in Column 3 of Table 2. The ecosystem services provided by each eco-zone are then identified according to aclassification system linking ecosystems and relevant services,established by the Millennium Ecosystem Assessment (2003). The 27 eco-zones provide 10types of ecosystem services: climate regulation and air quality maintenance, flood control and shoreline protection, nutrient regulation, waste treatment and control, nursery/habitats, fishery resources, maintenance of biodiversity, tourism/recreation, aesthetic/scenery, and scientific research and education (headings of column 4-13in Table 2).

\footnotetext{
${ }^{2}$ This study takes the $2 \%$ as the social discount rate
} 


\subsection{Ecosystem Valuation}

We estimate the unit values of ecosystem services in the Xiamen region using the methods detailed inPeng et al (2011) and new data. ${ }^{3}$ The value components associated with each service and data sources are summarized in Table 3. Results of the estimation are shown in Table 4. Marine and coastal ecosystems provides climate regulation and air quality maintenance services by capturing $\mathrm{CO}_{2}$, storing biological carbon, releasing $\mathrm{O}_{2}$, and accepting other gasesthrough photosynthesis in coastal plants (e.g., mangroves) and phytoplankton. Using data onprimary productivityineach zone, the cost of fixing $\mathrm{CO}_{2}, \mathrm{RMB} 270$ yuan $^{4} / \mathrm{t}\left(\mathrm{CO}_{2}\right)$ (Sumner et al., 2009), and production cost of $\mathrm{O}_{2}, 560$ yuan/t $\mathrm{t}^{5}$, we estimate the unit value for climate regulation service in each eco-zone, and the results range from RMB 0.05 to 0.28 yuan $/ \mathrm{m}^{2} \cdot \mathrm{yr}$ by location (Column 3 of Table 4).

Coastal wetland, such as mangroves, mudflats, sand beaches and coral reefs can dissipate waves, control floods and protect the shoreline. Han et al (2000) have estimatedthat the benefit of mangroves (with length $1 \mathrm{~km}$ and width $100 \mathrm{~m}$ ) for flood and storm control is RMB 80,000yuan per year.Thus, we calculate the value of flood control service as RMB 0.8 yuan $/ \mathrm{m}^{2}$ yrin eco-zoneswith mangroves, and RMB 0.32 yuan $/ \mathrm{m}^{2}$.yrin eco-zones with mudflats and sand beaches $(60 \%$ of that with mangroves) (Column 4 of Table 4).

Nutrient regulation services provided by the marine and coastal ecosystems can be broadly divided into two categories: providing the nutrients to marine species through food webs and their role as N and P sinks (Peng et al., 2011). The value of the former is reflected in services such as marine fishing and habitat. We only consider the valueof the latter to avoid double counting.If the oceans were not there, we would have to recreate this function by removing $\mathrm{N}$ and $\mathrm{P}$ from land runoffs(Costanza et al.,1997).Thus, the value of nutrient regulation can be estimated by the cost of

\footnotetext{
${ }^{3}$ For a broader discussion on measuring non-market and indirect effects of ecological damages, see Polasky(2002), NOAA (1997), and Mazzotta et al. (1994).

${ }^{4} \mathrm{RMB} 1$ yuan $=0.16$ US Dollar.

5 The average production cost of oxygen based on our survey of oxygen production factories in Xiamen.
} 
removing $\mathrm{N}$ and $\mathrm{P}$. The volume of nutrient containing wastewater discharged into the Xiamen sea area is $66.66 \times 10^{8} \mathrm{~m}^{3} / \mathrm{yr}$ (FJODMLG and MEL, 2006), and the area is $390 \mathrm{~km}^{2}$. Using the average treatmentcost of nutrient wastewater, 0.8 yuan $/ \mathrm{t}^{6}$, we estimate the value of nutrient regulation is $1.37 \mathrm{yuan} / \mathrm{m}^{2} \cdot \mathrm{yr}($ Column 5 of Table 4).

The marine and coastal waters can clean many kinds of pollution, including $\mathrm{N}$ and $\mathrm{P}$ as well as COD. We estimate the value of environmental carrying capacity of COD in the Xiamen sea area as RMB $0.60 \mathrm{yuan} / \mathrm{m}^{2} \cdot \mathrm{yr}$ (Peng et al, 2011). The value of waste treatment in eco-zones with sand beach and resort is zero because the wastewater discharge is prohibited in these areas (Column 6 of Table 4).

As noted, the different ecosystem services, such as habitats and fisheries,are inter-connected. To avoid double counting, the value of nursery habitats in the study only considerstheir functions to commercial shellfish. The values of habitats for commercial fisheries and for endangered species are captured in other services described below.Using data on primary productivity in each eco-zone and other biological parameters describedPeng et al. (2011),we estimate the value of habitat services in differenteco-zones ranging from RMB 1.14 to $2.51 \mathrm{yuan} / \mathrm{m}^{2} \cdot \mathrm{yr}($ Column 7 of Table 4).

The value of fisheries service is reflected by the profit of marine fishing. The Oceans and Fisheries Bureau of Xiamen (XMOFB,2004) surveyed the revenues and costs of marine fishing in differentsea areas. With the survey data, we estimate the value of fisheries in differenteco-zonesranging from RMB 0 to 0.16 yuan $/ \mathrm{m}^{2} \cdot \mathrm{yr}^{7}($ Column 8 of Table 4$)$.

The values of rare and endangered species can be used to represent the value of biodiversity service. The Coastal and Ocean Management Institute (COMI, 2009) estimated the value of endangered species, Chinese white dolphin, lancelet, and egret, in the Xiamen sea area using the contingent value method (CVM).Consideringthe contributions of different sea area to these species, we estimate the value of

\footnotetext{
${ }^{6}$ Based on data from sewage plants in Xiamen.

${ }^{7}$ A value of zero is assigned to zones with high-levels of pollution and no fishing activities.
} 
212 biodiversity in differenteco-zonesranging from RMB 1.08 to 2.78 yuan $/ \mathrm{m}^{2} \cdot \mathrm{yr}($ Column 2139 of Table 4).

214 Marine and coastal ecosystems provide important recreational services, such as 215 recreational fishing, swimming, and boating. Coastal waters, beaches, mangroves, and 216 coral reefs have considerable amenity value.According to Peng et al. (2004), the 217 willingness to pays (WTP) of Xiamen residents for fishable and boatable water are60 218 yuan/yrper person and 58.65 yuan/yr per person, respectively. COMI (2009) 219 calculated the WTP for sandy beach is 86 yuan/yr per person. With data on the total 220 population, ${ }^{8}$ area of beaches, ${ }^{9}$ and sea areas of Xiamen, we compute the value of 221 recreation service foreach eco-zone ranging from RMB0.43 to 4.80 yuan $/ \mathrm{m}^{2} \cdot \operatorname{yr}($ Column 10 of Table 4). According to Hong et al (2004), the WTP of 223 Xiamen residents for coastal scenery (excludingDadeng Sea) is RMB 94.95 $224 \mathrm{yuan} / \mathrm{m}^{2} \cdot \mathrm{yr}$. We calculate the value of scenic serviceas RMB $0.91 \mathrm{yuan} / \mathrm{m}^{2} \mathrm{yr}$ (Column 22511 of Table 4).

226 The marine and coastal ecosystems also provide fundamentals for formal or informal education, as well as scientific research. Using the estimates of Costanza et al. (1997), we assign the value of scientific research as RMB $0.05 y u a n / \mathrm{m}^{2} \mathrm{yr}($ Column 12 of Table 4). Aggregating across ecosystem services, we find that the highest total ecosystem value (RMB $12.55 \mathrm{yuan} / \mathrm{m}^{2} \cdot \mathrm{yr}$ ) is associated with eco-zone, ES1, in the

231 Eastern Sea, while the lowest total ecosystem value (RMB $6.41 \mathrm{yuan} / \mathrm{m}^{2} \cdot \mathrm{yr}$ ) is associated with other areas in the Dadeng Sea (Last Column of Table 4; Figure 3).

\subsection{Damage Severity}

The Delphi methodis used to solicit expert assessments on the severities of damages to different ecosystem services by different ocean uses. A panel of 32 experts is involved in the survey, and their field of expertise is shown in Table 5. These ocean science and management experts are familiarwith Xiamen's ocean environment and economic activities, and they are affiliated with ocean management agencies,

\footnotetext{
${ }^{8}$ The population is 2.42 million in 2009 (XSB, 2010).

9 The area of sand beach is $42.8 \mathrm{~km}^{2}$.
} 
universities, oceanographic institutes, port authority, and an ocean engineering firm in Xiamen.

The set of 14 ocean uses included in the survey is listedin the first column of Table 6. The experts rank the damage severity on a scale of $0-100$, and two rounds of mail surveys were conducted to achieve consistent results. The final average scores are rescaled to a factor of $0-1$. The damage severity factors by ecosystem services and by ocean uses are summarized in Table 6 . The severity factor for land reclamation is one because it is associated with a total destruction. Other ocean uses with high ecological damages include impermeable structures (e.g., jetty or breakwater) and mining.

\section{Results}

The MEDC standard can be calculated using methods and equationsdescribed in Section 2 and data from Tables 4 and 6, and the results are shown in Table 7. All the units are in annual value per unit area (RMB yuan $\left./ \mathrm{m}^{2} . \mathrm{yr}\right)$, except for four uses, land reclamation, impermeable structure, sea bridge, and permeable structure. Land reclamation leads to permanent losses to relevant ecosystem services.A lump-sum payment is estimated as RMB 321-628 yuan per square meter depending on the location. This figure is much higher than current sea area use charge which is RMB $180 \mathrm{yuan} / \mathrm{m}^{2}$. That is to say current sea areas use charge standard does not internalize the externality of human activities, which is one of the causes of the marine ecosystem damage.

Similarly, lump-sum compensations are computed for stationary structures (assuming a 50 -year life) ${ }^{10}$. We see that the standard for impermeable structures ranging $\mathrm{RMB} 98-166 \mathrm{yuan} / \mathrm{m}^{2}$ is considerably higher than that for permeable structures (e.g., dock on pilings), reflecting the differences in ecological damages. The annual compensation for coastal aquaculture (RMB $0.62-1.31 \mathrm{yuan} / \mathrm{m}^{2} . \mathrm{yr}$ ) is also greater than that for offshore aquaculture (RMB $0.44-1.01$ yuan $/ \mathrm{m}^{2} . \mathrm{yr}$ ), because the

\footnotetext{
${ }^{10}$ The statutory maximum life of stationary structures is 50 years according to Sea Area Use Management Law of PRC (SAUML) promulgated in 2001 (Article 25)
} 
former typically causes more ecological alterations then the latter. In terms of spatial variation, the ecologically more valuable Eastern Sea area is generally associates with higher MEDC values.

\section{Discussion}

Under existing sea area use charge regime in China, ocean users must pay user fees to local ocean management agencies for various operations (e.g., land reclamation, aquaculture, and coastal construction). The fees collected are distributed among the central, provincial, and local governments (30\%, 30\% and $40 \%$ ). The user fees are designed to recover resource rents generated from sea area usage (like a land rent) and do not reflect damages to the ecosystem. Thus, the user fee is too low to regulate excessive development in many coastal areas. The newly proposed MEDC standard is designed to address this issue. ${ }^{11}$

The MEDC program should be formulated and operated at the local level, so that the local government collects the compensation payments which, in turn, will be used for ecosystem restoration and protection in the same region. As noted in section 2 , the Xiamen People's Congress promulgated Several Regulations of Marine Environmental Protection in 2010, and Article 18 called for the implementation of a compensation regime for marine ecological damages resulted from sea area uses. The study reported here is developed to assist this effort. Other studies are needed to develop detailed rules implementing the compensation standard, including methods on fee collection (annual vs. lump-sum payments) and on distribution(among different ecological restoration options).

The interactions between coastal ecosystems and the human system are extremely complex involving multiple pathways and feedbacks. Estimating the impacts of different ocean uses on different ecosystem services can be very costly and time consuming, and an accurate estimation may not always be feasible. To

\footnotetext{
${ }^{11}$ In addition to Xiamen, Shangdong, a Yellow Sea coastal province in northern China, is also formulating a MEDC program.
} 
293 implement MEDC for relatively small scale ${ }^{12}$ and common ocean uses, it makes 294 sense to develop a simplified approach for a rapid assessment for associated marine 295 ecosystem damages. This is in the same spirit of the Type A assessment for oil spill 296 damages using the natural resource damage assessment model (NRDAM) in the 297 United States (Grigalunas et al., 1988).

298 Although the MEDC standard developed in the study presents a potentially 299 effective way to control unsustainable development in Xiamen, our framework has 300 several limitations.First, several ecosystem damage costs are modeled as linear 301 functions in the study. However, many of these costs are nonlinear due to nonlinear 302 interactions in the natural systems (Barbier et al., 2008). In addition, we do not have 303 a good understanding of the ecological thresholds in the study area. When a system 304 crosses a threshold, a very small change in economic activity can have enormous 305 impacts and result in irreversible loss of critical natural capital (Farley, 2012).Finally, 306 the natural and socioeconomic systems are highly complex and dynamic. Our static 307 model cannot capture the full effects of the dynamic interactions in the coastal 308 systems. Sustainabledevelopment is an evolutionary process, and sustainability is not 309 a static objective. Thus, an adaptive management system must be in place to cope 310 with various uncertainties (Rammel et al.,2007). In fact, our estimation of the 311 MEDC standard for Xiamen should not be viewed as static, and it should be 312 reevaluated periodically so that new knowledge can be incorporated into the 313 compensation standard.The effectiveness of MEDC standard should be evaluated 314 based on regional performance indicators capturing changes in socioeconomic 315 well-being and ecosystem conditions (Yu e al., 2010; Seingier et al., 2011; Smith et al., 316 2013).

317 The paper presents a general framework to develop MEDC standard for a coastal 318 location. The framework is transferable to other locations with different ecosystems. 319 Although the study focuses on the economic valuation of ecosystem services, there is 320 a close connection between an ecological compensation standard and corresponding

\footnotetext{
${ }^{12}$ In Xieman, small scale is defined as: $<10$ ha for land reclamation, $<50$ ha for exclusive uses (e.g., harbor, aquaculture, and salt making), and $<100$ he for other uses.
} 
social setting. The MEDC standard is site specific and are affected a number of social factors. In the study, the MEDC standard is developed for Xiamen using different market and non-market valuation methods. Both market and non-market valuation results are affected by local social and economic conditions (e.g., population, income, education level,economic structure, and institutional and cultural factors).

Calculating the ecological compensation standards for different locations requires a good understanding of economic valuation of ecological goods and services in different social and economic settings as well as the strength and limitations of different valuation methods (Whittington, 1998; Bishop, 1999; Boyd and Wainger, 2003; Swallow et al., 2009; Vo et al., 2012). In study, we use CVM studies conducted in Xiamen for the MEDC standard calculation for the same location. MEDC standards for other regions of China are typically based on CVM studies in relevant locations to reflect local social and economic conditions. Generally, in developing MEDC standard, local valuation data should be used, if available. The local data can be supplemented with data from nearby region or countries with similar social and economic conditions. International valuation data can be used with appropriate benefit-transfer techniques, when local data are not available.

\section{Conclusion}

Coastal and marine ecosystems and the environment are vital to the well-being of coastal communities. To achieve sustainability, coastal managers must control excessive economic activities. A mechanism of marine ecological damage compensation (MEDC) has been introduced in China. MEDC is designed to implement the polluter pays principle through a market-based approach.

Almost all ocean uses will lead to some level of damages to the ecosystems. Quantification of these damages, especially in monetary terms, is often difficult and costly. However, the fact that ecological damages are unquantifiable should not result in an exemption from compensation. On the other hand, the compensation should not be exorbitant and punitive for regular and routine marine activities.

We have developed a framework for formulatingthe MEDC standard and applied 
351 it to the Xiamen region. The standard providesa low-cost and convenient way to

352 implement MEDC. It is calculated using methods from resource and ecological 353 economics, and takes into account spatial variations in ecological conditions as well 354 as the knowledge of local marine science and management experts. The approach is 355 transferable to other locations, and the MEDC standard can be easily updated over 356 time as new estimation methods and data become available.

358 Acknowledgements We would like to express our appreciation to Dr. Rongbiao Hong 359 for beneficial discussions regarding various aspects of this study. The study was 360 funded by the National Oceanic Public Welfare Projects (No. 201105006)and the 361 Oceans and Fisheries Bureau of Xiamen ([2010]60).

362

363 


\section{References}

Airoldi, L., Beck, M.W., 2007. Loss, status and trends for coastal marine habitats of Europe. Oceanography and Marine Biology: An Annual Review.45, 345-405.

Barbier, E.B., Koch, E.W., Silliman, B.R., Hacker, S.D., Wolanski, E., Primavera, J., Granek, E.F., Polasky, S., Aswani, S., Cramer, L.A., Stoms, D.M., Kennedy, C.J., Bael, D., Kappel, C.V., Perillo, J.M.E., Reed, D.J., 2008. Coastal ecosystem-based management with nonlinear ecological functions and values. Science. 319, 321-323.

Bishop, J.T., 1999. Valuing Forests: A Review of Methods and Applications in Developing Countries.International Institute for Environment and Development: London.

Boyd, J., Wainger,L., 2003. Measuring Ecosystem Service Benefits: The Use of Landscape Analysis toEvaluate Environmental Trades and Compensation. Discussion Paper 02-63. Resources for the Future, Washington, DC.

Cai, L.,2008. The discipline of multiple red tide and its relationship with the natural factors in Xiamen Sea area. Journal of Fujian Fisheries. 6(2), 75-79.

Cendrero, A., Díaz de Terán, J.R., Salinas, J.M., 1981. Environmental-economic evaluation of the filling and reclamation process in the bay of Santander, Spain.Environmental Geology. 3(6), 325-336.

Chen, Y.F., 1994. Estimation of Forest Environmental And Resource Value of China. China Forestry Science Research Institute, Beijing.

Chen, X.Q., Chen, Q.H., Zhang, M.,2002. Primary productivity in eastern sea area of Xiamen. Journal of Oceanography in Taiwan Strait. 21(2), 217-223.

China Council for International Cooperation on Environment and Development (CCICED), Task Force on Eco-Compensation Mechanisms and Policies,2007. Eco-Compensation Mechanisms and Policies in China. China Environmental Science Press, Beijing.

China Council for International Cooperation on Environment and Development (CCICED), 2012. CCICED Annual Policy Report (2011). China Environmental Science Press, Beijing.

Coastal and Ocean management Institute (COMI), 2009. The Research of Environmental Values in Xiamen Marine Natural Reserves. Xiamen University, Xiamen,Xiamen. 
Costanza, R., d'Arge, R., de Groot, R., Farberk, S., Grasso, M., Hannon, B., Limburg, K., Naeem, S., O’Neill, R.V., Paruelo, J., Raskin, R.G., Sutton, P., van den Belt, M., 1997. The value of the world's ecosystem services and natural capital. Nature. 387, 253-260.

De Groot, R.S., Wilson, M.A., Boumans, R.M.J.,2002. A typology for the Ecological Economics. 41, 393-408.

De Mulder, E.F.J., Bruchem, A,J., Claessen, F.A.M., Hannink, G., Hulsbergen, J.G., Satijn, H.M.C., 1994. Environmental impact assessment on land reclamation projects in the Netherlands: a case history. Engineering Geology. 37(1), 15-23.

Elliott, M., Cutts, N.D.,2004. Marine habitats: loss and gain, mitigation and compensation. Marine Pollution Bulletin. 49, 671-674.

FAO, 1999. Understanding the Ecological Impact of Tideland Reclamation. Available at http://www.fao.org/sd/EPdirect/EPan0013.html.

Farley, J., 2012. Ecosystem services: the economics debate. Ecosystem Services. 1, 40-49.

Fujian Ocean Development and Management Leader Group (FJODMLG) and the State Key Laboratory of Marine Environmental Science (MEL), 2006.The Assessment and Estimation of Nearshore Environmental Capacity.Xiamen University,Xiamen.

Goldburg, R.J., Elliott, M.S., Naylor, R.L., 2001. Marine Aquaculture in the United States. Pew Oceans Commission, Arlington, Virginia.

Grigalunas, T.A., Opaluch, J.J., French, D., Reed, M., 1988. Measuring damages to marine natural resources from pollution incidents under CERCLA: application of an integrated ocean systems/economic model. Marine Resource Economics. 5(1), 1-21.

Halpern, B.S., Walbridge, S., Selkoe, K.A., Kappel, C.V., Micheli, F., D’Agrosa, C., Bruno, J.F., Casey, K.S., Ebert, C., Fox, H.E., Fujita, R., Heinemann, D., Lenihan, H.S., Madin, E.M.P., Perry, M.T., Selig, E.R., Spalding, M., Steneck, R., Watson, R.A., 2008. A global map of human impact on marine ecosystems. Science. 319, 948-952.

Han, W.D., Gao, X.M., Lu, C.Y., Lin, P.,2000. Estimation of ecological value of mangroves ecosystem in China. Ecological Science. 19(1), 40-46.

He, B.Y., Fan, H.Q., Wang, M., Lai, T.H., Wang, W.Q.. 2007. Species diversity in 
mangrove wetlands of China and its causation analysis. Acta Ecological Sinica.27(11), 4859-4870.

Hoeksema, R.J.,2007. Three stages in the history of land reclamation in the Netherlands. Irrigation and Drainage.56(s1), 113-126.

Hong, H.S., Peng, B.R., Zhou, L.M., Xue, X.Z., Gao, C.T.,2004. Socio-economic analysis of integrated treatment of West Sea. Environmental Science Research Center, Xiamen University, Xiamen.

Kim, I., 2003.A comparison between the international and US regimes regulating oil pollution liability and compensation. Marine Policy. 27, 265-279.

Leader Group Office (LGO) of Integrated Survey in Xiamen Island Resources, 1996.Survey Report of Xiamen Island Resources. Ocean Press, Beijing.

Lloret, J., Zaragoza, N., Caballero, D., Riera, V., 2008. Impacts of recreational boating on the marine environment of Cap de Creus (Mediterranean Sea). Ocean \& Coastal Management. 51, 749-754.

Mason, M., 2003. Civil liability for oil pollution damage: examining the evolving scope for environmental compensation in the international regime. Marine Policy. 27, $1-12$

Mazzotta, M.J., Opaluch, J.J., Grigalunas, T.A.,1994. Natural resource damage assessment: the role of resource restoration. Natural Resources Journal. 34, 153-178.

McCay, D.P.F., Whittier, N., Ward, M., Santos, C., 2006. Spill hazard evaluation for chemicals shipped in bulk using modeling. Environmental Modelling\& Software.21(2), 156-169.

Millennium Ecosystem Assessment Board (MEAB), 2003. Ecosystems and Human Well-being: A Framework for Assessment. Island Press, Washington, DC.

NOAA, 1997. Natural Resource Damage Assessment Guidance Document: Scaling Compensatory Restoration Actions (Oil Pollution Act of 1990). Damage Assessment and Restoration Program, National Oceanic and Atmospheric Administration, Silver Spring, Maryland.

OSPAR Commission, 2008. Assessment of the environmental impact of land reclamation. Available at http://qsr2010.ospar.org/media/assessments/p00368_Land_Reclamation.pdf.

Peng, B., Jin, D., Burroughs, R., 2009. Regional ocean governance in China: an appraisal of the Clean Bohai Sea Program. Coastal Management. 37(1), 70-93. 
Peng, B.R., Hong, H.S., Chen, W.Q., Xue, X.Z., 2004. Evaluation of coastal environment and resources: theory, methods and application. Journal of Xiamen University (Natural Science).43(s), 184-189.

Peng, B., Chen, W., Hong, H.,2011. Integrating ecological damages into the user charge for land reclamation: a case study of Xiamen, China. Stochastic Environmental Research Risk Assessment. 25(3), 341-351.

Peng, B., Hong, H., 2006. Evaluation of Coastal Ecosystem Services-Theory and Application. Ocean Press, Beijing.

Polasky, S., 2002. The economics of wetland ecosystem restoration and mitigation: discussion. American Journal of Agriculture Economics. 84(5), 1379-1380.

Rammel, C., Stagl, S., Wilfing, H., 2007. Managing complex adaptive systems - a co-evolutionary perspective on natural resource management. Ecological Economics. 63(1), 9-21.

Ryan, J.T., 1994. The evolution of natural resource damage assessments under the Oil Pollution Act and the Comprehensive Environmental Response, Compensation, and Liability Act. Fordham Environmental Law Review. 6(1), 29-49.

Seingier, G., Espejel, I., Fermán-Almada, J.L., González, O.D., Montano-Moctezuma, G., Azuz-Adeathd, I., Aramburo-Vizcarra, G., 2011. Designing an integrated coastal orientation index: a cross-comparison ofMexican municipalities. Ecological Indicators. 11, 633-642.

Smith, L.M., Case, J.L., Smith, H.M., Harwell, L.C., Summers, J.K., 2013. Relating ecoystem services to domains of human well-being: Foundation for a U.S. index. Ecological Indicators. 28, 79-90.

State Oceanic Administration (SOA),2009. Several Opinions on Better Protection and Construction of Marine Ecosystem. State Oceanic Administration, Beijing.

Sumner, J., Bird, L., Smith, H.,2009. Carbon Taxes: A Review of Experience and Policy Design Considerations. Technical Report NREL/TP-6A2-47312.National Renewable Energy Laboratory. Golden, Colorado.

Swallow, B.M., Kallesoe, M.F., Iftikhar, U.A., van Noordwijk, M., Bracer, C., Scherr, S.J., Raju, K.V., Poats, S.V., Duraiappah, A.K., Ochieng, B.O., Mallee, H., Rumley, R., 2009. Compensation andrewards for environmental services in the developing world: framing pan-tropical analysis and comparison. Ecology and Society. 14(2), 26. available at http://www.ecologyandsociety.org/vol14/iss2/art26/ 
United Nations Environment Programme (UNEP), 2002. State of the Environment

540 and Policy Retrospective: 1972-2002. UNEP GEO-3, 2002.Available at

541 http://www.unep.org/ geo/ GEO3/ english/ pdfs/ chapter2-1_socioeconomic.pdf.

543 Vo, Q.T., Kuenzerb, C., Vo, Q.M., Moder, F., Oppelt, N., 2012. Review of valuation methods for mangrove ecosystem services. Ecological Indicators. 23, 431-446.

Wang X., Chen, W.Q., Zhang, L.P., Guo, W., 2010a. Predictive valuation of ecosystem services losses from sea reclamation planning projects in Tong'an Bay. ActaEcologicaSinica. 30( 21), 5914-5924.

Wang, X., Chen, W.Q., Jiang, Y.W., Zhang, L.P.,2010b. Evaluation of losses in bay environmental capacity based on numerical simulation - a case study of sea reclamation Tong'an Bay, Xiamen. China Environmental Science. 30(3), 420-425.

Whittington, D. 1998. Administering contingent valuation surveys in developing countries. World Development. 26(1), 21-30.

Xiamen Oceans and Fisheries Bureau (XMOFB), 2004. The Report of Fisheries in the Western and Eastern Sea Areas of Xiamen. Oceans and Fisheries Bureau, Xiamen.

Xiamen StatisticBureau(XSB). 2010. Yearbook of Xiamen Special Economic Zone (2010). Chinese Statistic Press, Beijing.

Yu, L., Hou, X., Gao, M., Shi, P., 2010. Assessment of coastal zone sustainable 565 


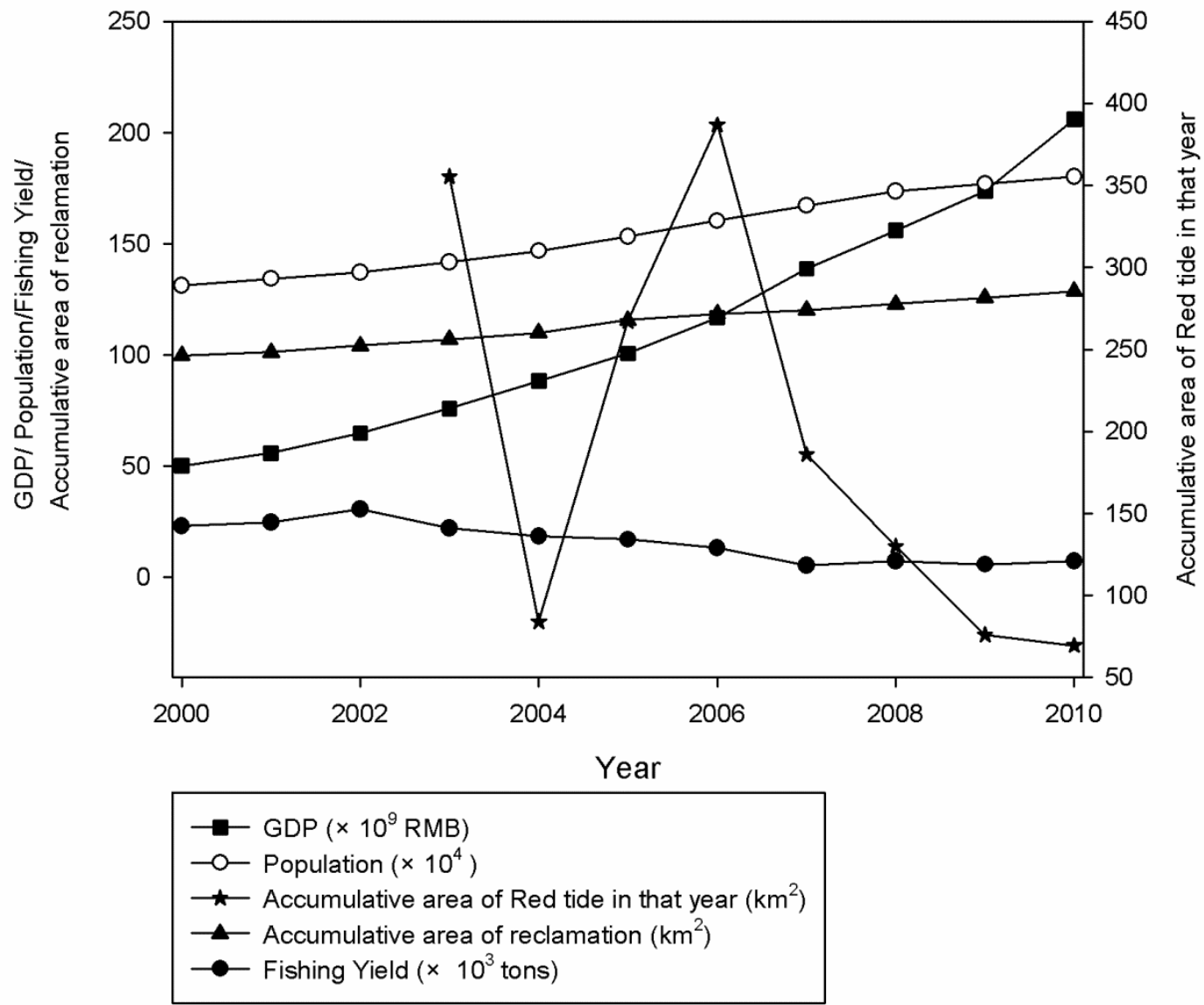

Figure 1.Socioeconomic Development and Ecosystem Conditions in Xiamen, 2000-2010 


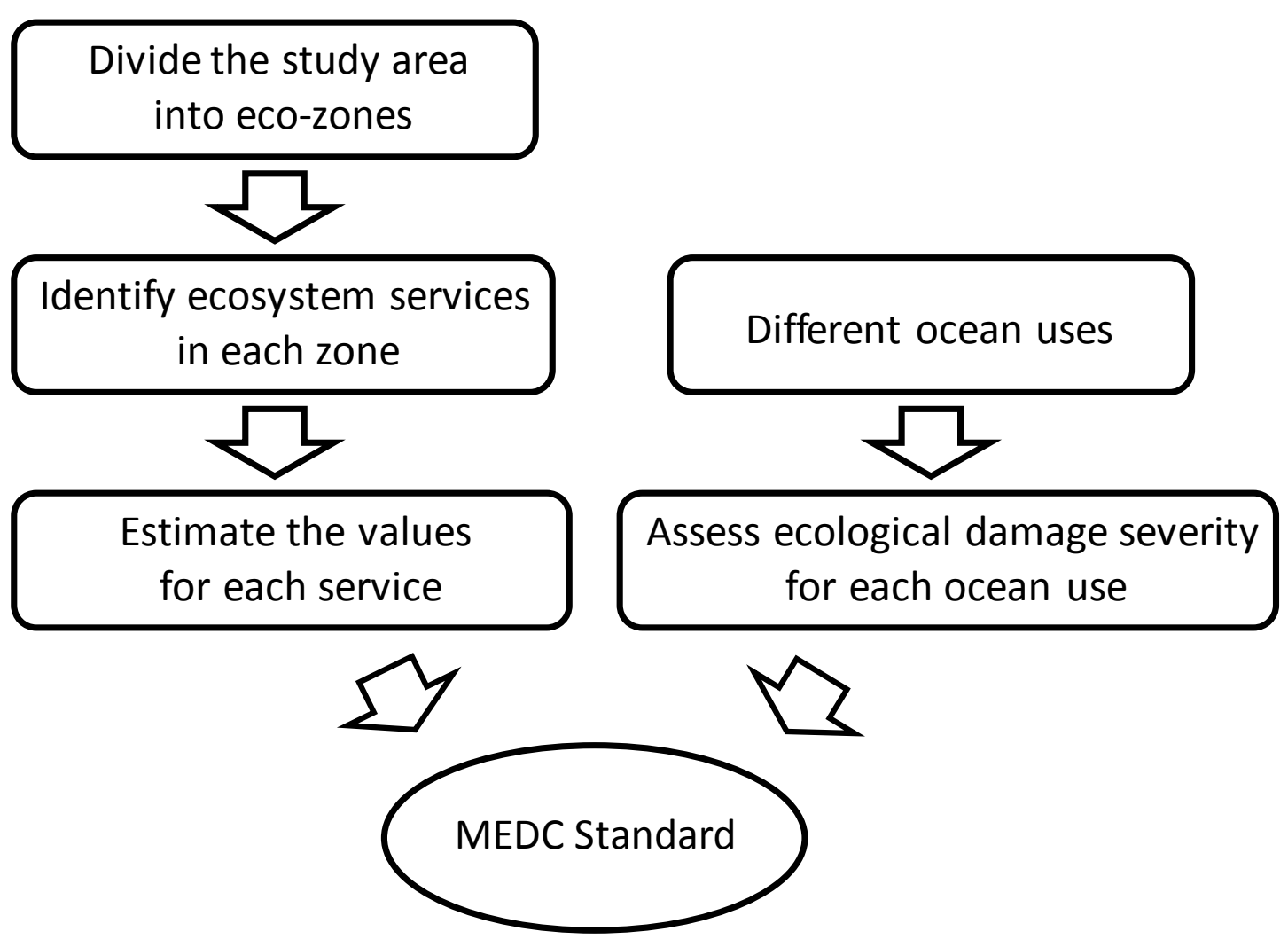




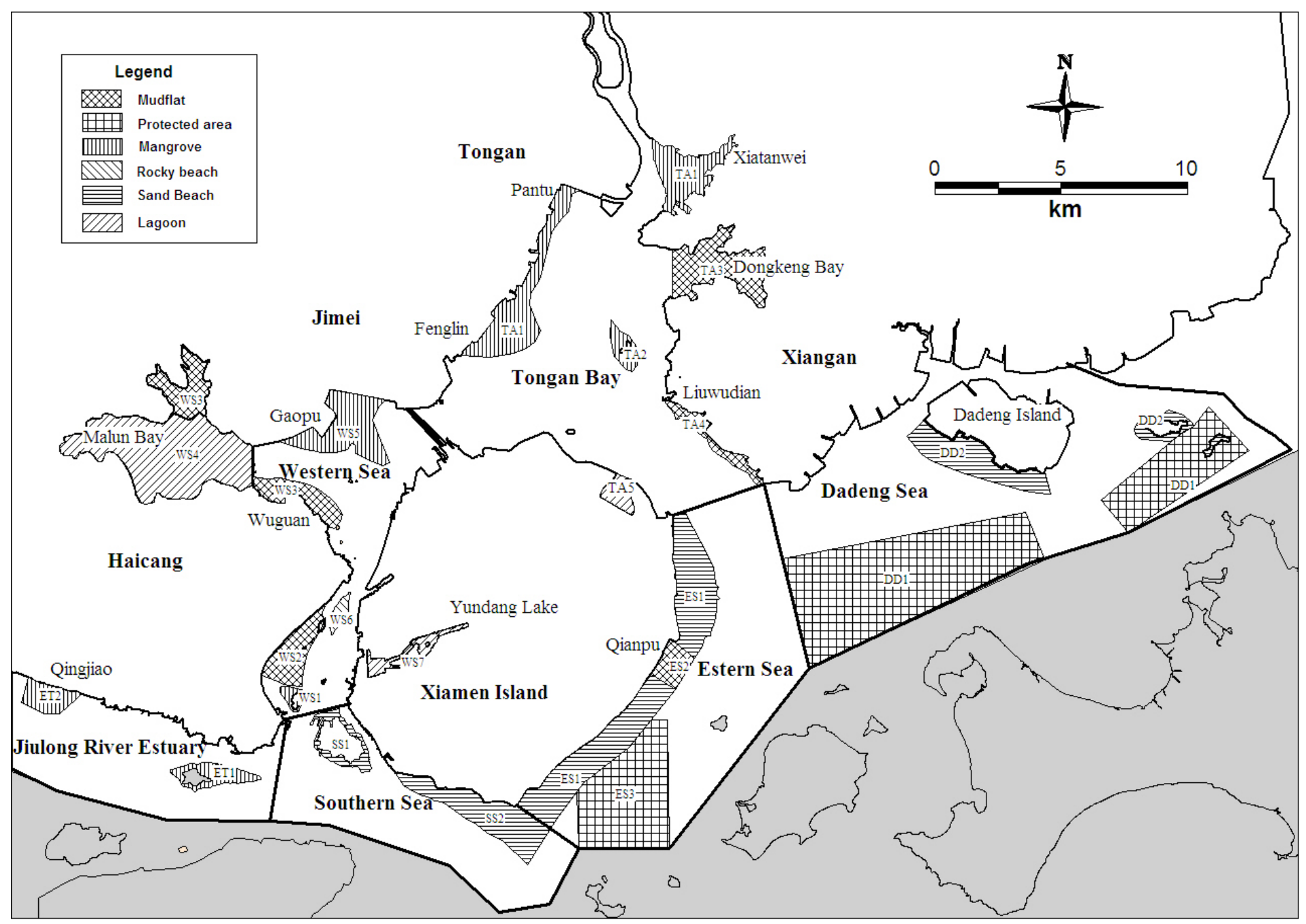

Figure 3.Eco-zonesin Xiamen Sea Area 


\begin{tabular}{|l|r|}
\hline Ecosystems & \multicolumn{1}{|l|}{ Index } \\
\hline Cliff & 1 \\
\hline Rocky beach & 2 \\
\hline Mudflat & 3 \\
\hline Sand beach & 4 \\
\hline Mangrove & 5 \\
\hline Lagoon & 6 \\
\hline Estuary & 7 \\
\hline Coastal water & 8 \\
\hline
\end{tabular}

582 
Table 2.Identification of Ecosystems and Ecosystem Services in Xiamen Sea Areas

\begin{tabular}{|c|c|c|c|c|c|c|c|c|c|c|c|c|}
\hline \multirow{2}{*}{$\begin{array}{c}\text { Managem } \\
\text { ent } \\
\text { Areas }\end{array}$} & \multirow[b]{2}{*}{$\begin{array}{l}\text { Eco- } \\
\text { zones }\end{array}$} & \multirow[b]{2}{*}{ Ecosystems } & \multicolumn{10}{|c|}{ Ecosystem Services } \\
\hline & & & $\begin{array}{l}\text { Climate } \\
\text { regulation }\end{array}$ & $\begin{array}{c}\text { Flood } \\
\text { control/shoreline } \\
\text { protection }\end{array}$ & $\begin{array}{l}\text { Nutrient } \\
\text { regulation }\end{array}$ & $\begin{array}{c}\text { Waste } \\
\text { treatment/ } \\
\text { control }\end{array}$ & $\begin{array}{l}\text { Nursery/ } \\
\text { habitats }\end{array}$ & Fisheries & Biodiversity & Recreation & Aesthetic & $\begin{array}{l}\text { Scientific } \\
\text { research/ } \\
\text { education }\end{array}$ \\
\hline \multirow{8}{*}{$\begin{array}{c}\text { Western } \\
\text { Sea }\end{array}$} & WS1 & $2,3,5,8$ & ○ & o & ○ & ○ & $\circ$ & ○ & ○ & ○ & ○ & $\circ$ \\
\hline & WS2 & $3,5,8$ & o & o & o & o & ○ & $\circ$ & o & o & o & $\circ$ \\
\hline & WS3 & $2,3,4,5,8$ & o & o & o & o & o & & o & o & o & ○ \\
\hline & WS4 & $3,5,6$ & ○ & & $\circ$ & ○ & $\circ$ & ○ & $\circ$ & o & ○ & $\circ$ \\
\hline & WS5 & 3,5 & ○ & $\circ$ & ○ & ○ & $\circ$ & & $\circ$ & ○ & ○ & $\circ$ \\
\hline & WS6 & $2,5,8$ & ○ & ○ & $\circ$ & ○ & $\circ$ & & o & ○ & ○ & $\circ$ \\
\hline & WS7 & $3,5,6$ & o & o & o & o & o & & o & o & o & o \\
\hline & others & & ○ & $\circ$ & ○ & ○ & $\circ$ & ○ & o & o & ○ & $\circ$ \\
\hline \multirow{3}{*}{$\begin{array}{c}\text { Estuary } \\
\text { Sea }\end{array}$} & ET1 & $2,3,5,7,8$ & o & ○ & ○ & ○ & ○ & $\circ$ & 0 & 0 & 0 & o \\
\hline & ET2 & $2,3,5,7$ & o & o & ○ & o & o & ○ & o & o & o & ○ \\
\hline & others & & o & o & 0 & o & o & 0 & o & o & o & ○ \\
\hline \multirow{6}{*}{$\begin{array}{c}\text { Tongan } \\
\text { Sea }\end{array}$} & TA1 & $2,3,5$ & o & o & o & o & o & o & o & o & o & ○ \\
\hline & TA2 & $3,4,5,8$ & 0 & 0 & o & 0 & o & o & 0 & 0 & 0 & o \\
\hline & TA3 & 3,8 & o & & o & ○ & ○ & ○ & o & o & o & ○ \\
\hline & TA4 & 3,4 & o & & o & o & o & o & o & o & o & o \\
\hline & TA5 & 6 & o & o & ○ & o & o & & 0 & 0 & 0 & 0 \\
\hline & others & & 0 & & 0 & o & 0 & 0 & 0 & 0 & o & 0 \\
\hline
\end{tabular}




\begin{tabular}{|c|c|c|c|c|c|c|c|c|c|c|c|c|}
\hline \multirow{3}{*}{$\begin{array}{c}\text { Southern } \\
\text { Sea }\end{array}$} & SS1 & $1,2,3,4,8$ & O & ○ & O & & ○ & ○ & 0 & ○ & o & O \\
\hline & SS2 & $2,4,8$ & O & O & 0 & & O & ○ & O & ○ & ○ & ○ \\
\hline & others & & $\circ$ & ○ & 0 & O & O & O & 0 & 0 & ○ & O \\
\hline \multirow{4}{*}{$\begin{array}{c}\text { Eastern } \\
\text { Sea }\end{array}$} & ES1 & $2,3,5,8$ & o & ○ & 0 & & ० & ○ & ○ & ○ & o & ○ \\
\hline & ES2 & $2,4,8$ & O & O & 0 & O & ○ & ○ & 0 & 0 & O & ○ \\
\hline & ES3 & 8 & ० & & O & & ० & ○ & ○ & ○ & ० & O \\
\hline & others & $2,3,4,5,8$ & 0 & O & ○ & O & O & ○ & ○ & ○ & ○ & ○ \\
\hline \multirow{3}{*}{$\begin{array}{c}\text { DadengSe } \\
\text { a }\end{array}$} & DD1 & 8 & ० & & O & o & ○ & ○ & 0 & 0 & o & O \\
\hline & DD2 & 3,4 & 0 & O & 0 & & ० & ○ & $\circ$ & ○ & ○ & o \\
\hline & others & & 0 & & 0 & 0 & 0 & 0 & 0 & 0 & 0 & 0 \\
\hline
\end{tabular}




\begin{tabular}{|c|c|c|}
\hline Ecosystem Services & Value Components & Data Sources \\
\hline $\begin{array}{l}\text { Climate regulation and } \\
\text { air quality } \\
\text { maintenance }\end{array}$ & $\begin{array}{l}\text { Costs of fixing } \mathrm{CO}_{2} \text { and } \\
\mathrm{O}_{2} \text { production }\end{array}$ & $\begin{array}{l}\text { LGO (1996), Chen et al } \\
(1994), \text { He et al. (2007), } \\
\text { Sumner et al.(2009) }\end{array}$ \\
\hline $\begin{array}{l}\text { Flood Control and } \\
\text { shoreline protection }\end{array}$ & $\begin{array}{l}\text { Value of mangroves for flood } \\
\text { control }\end{array}$ & Han et al. (2000) \\
\hline Nutrient regulation & $\begin{array}{l}\text { Cost of removing } \mathrm{N} \text { and } \mathrm{P} \text { in } \\
\text { wastewater }\end{array}$ & $\begin{array}{l}\text { FJODMLG and } \\
\text { MEL( 2006),Xiamen } \\
\text { Sewage Plants }\end{array}$ \\
\hline Waste treatment & $\begin{array}{l}\text { Cost of COD treatment in } \\
\text { wastewater }\end{array}$ & Peng et al. (2011) \\
\hline Nursery/ Habitats & $\begin{array}{l}\text { Value of habitat to commercial } \\
\text { shellfish }\end{array}$ & $\begin{array}{l}\text { LGO (1996), Chen et al } \\
\text { (2002),Peng et. al. (2011) }\end{array}$ \\
\hline Fishery & Value of marine fishing & XMOFB (2004) \\
\hline Biodiversity & Value of endangered species & COMI (2009) \\
\hline Recreation & Value of coastal recreation & $\begin{array}{l}\text { Peng et al. (2004), COMI } \\
(2009)\end{array}$ \\
\hline Esthetic value & Value of coastal scenery & Hong et al. (2004) \\
\hline
\end{tabular}


Table 4.Ecosystem Services and Their Values

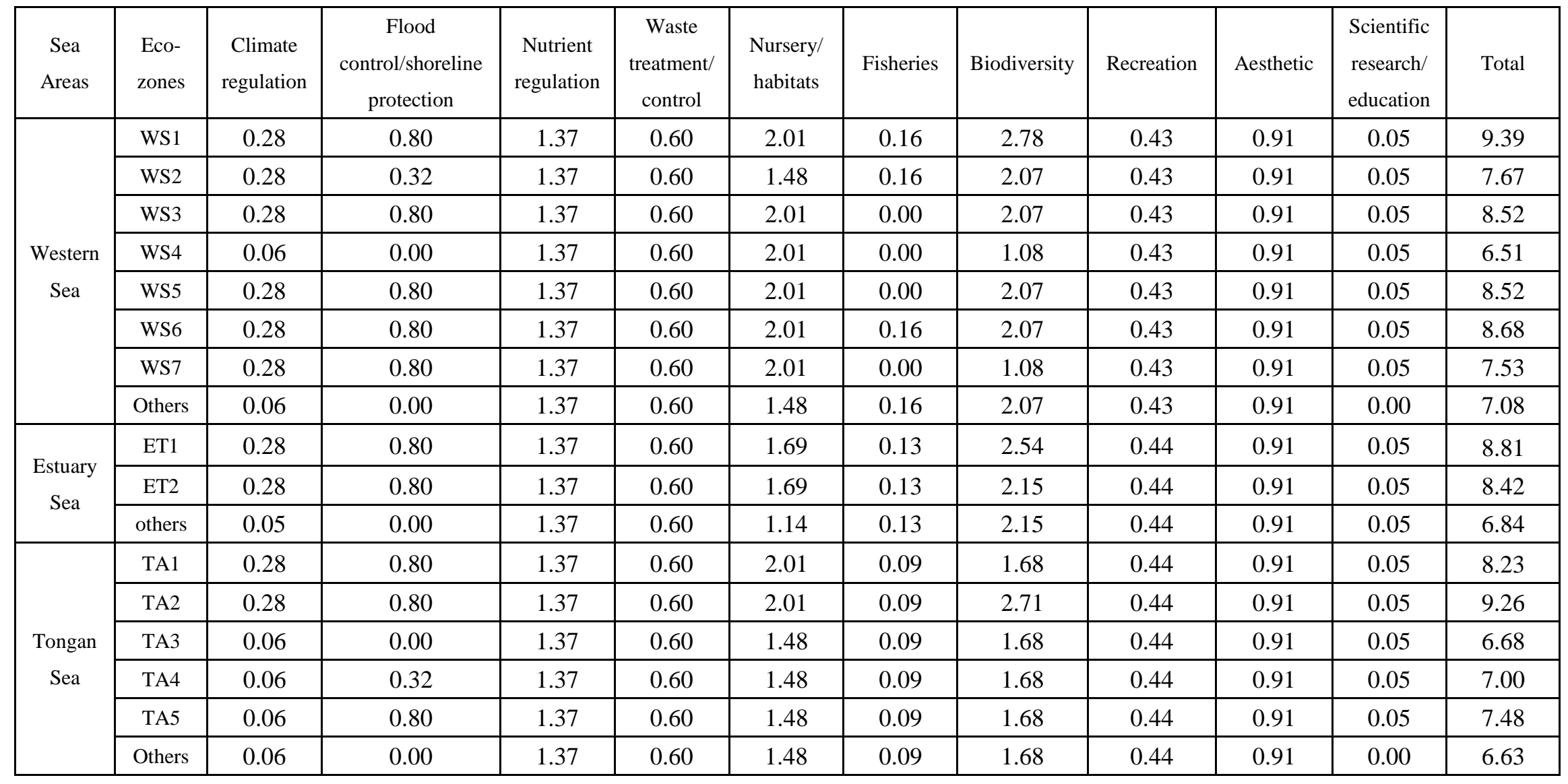

592 


\begin{tabular}{|c|c|c|c|c|c|c|c|c|c|c|c|c|}
\hline \multirow{3}{*}{$\begin{array}{c}\text { Souther } \\
\text { n Sea }\end{array}$} & SS1 & 0.28 & 0.80 & 1.37 & 0.00 & 2.01 & 0.06 & 1.63 & 4.80 & 0.91 & 0.05 & 11.91 \\
\hline & SS2 & 0.28 & 0.32 & 1.37 & 0.00 & 2.01 & 0.06 & 1.63 & 4.80 & 0.91 & 0.05 & 11.43 \\
\hline & Others & 0.06 & 0.00 & 1.37 & 0.60 & 2.01 & 0.06 & 1.63 & 0.44 & 0.91 & 0.05 & 7.13 \\
\hline \multirow{4}{*}{$\begin{array}{c}\text { Eastern } \\
\text { Sea }\end{array}$} & ES1 & 0.31 & 0.80 & 1.37 & 0.00 & 2.51 & 0.03 & 1.77 & 4.80 & 0.91 & 0.05 & 12.55 \\
\hline & ES2 & 0.31 & 0.32 & 1.37 & 0.00 & 2.51 & 0.03 & 1.77 & 0.44 & 0.91 & 0.05 & 7.71 \\
\hline & ES3 & 0.31 & 0.00 & 1.37 & 0.00 & 2.51 & 0.03 & 2.32 & 4.80 & 0.91 & 0.05 & 12.30 \\
\hline & others & 0.10 & 0.00 & 1.37 & 0.60 & 2.51 & 0.03 & 1.77 & 0.44 & 0.91 & 0.05 & 7.78 \\
\hline \multirow{3}{*}{$\begin{array}{c}\text { Dadeng } \\
\text { Sea }\end{array}$} & DD1 & 0.05 & 0.00 & 1.37 & 0.60 & 1.20 & 0.09 & 2.24 & 0.44 & 0.91 & 0.05 & 6.95 \\
\hline & DD2 & 0.28 & 0.32 & 1.37 & 0.00 & 1.20 & 0.09 & 1.70 & 1.92 & 0.91 & 0.05 & 7.84 \\
\hline & others & 0.05 & 0.00 & 1.37 & 0.60 & 1.20 & 0.09 & 1.70 & 0.44 & 0.91 & 0.05 & 6.41 \\
\hline
\end{tabular}

Unit: RMB yuan $/ \mathrm{m}^{2}$.yr.RMB 1 yuan $=0.16$ US Dollar. 


\begin{tabular}{|l|r|}
\hline Field of Expertise & Number of Experts \\
\hline Environmental impact & 4 \\
assessment & 6 \\
\hline Marine ecology & 4 \\
\hline Marine economics & 2 \\
\hline Marine environmental sciences & 3 \\
\hline Marine fisheries & 3 \\
\hline Ocean administration & 4 \\
\hline Ocean engineering & 4 \\
\hline Ocean management & 2 \\
\hline Physical oceanography & 32 \\
\hline Total & \\
\hline
\end{tabular}

597 
Table6.Damage Severityto Ecosystem Services by Different Ocean Uses

\begin{tabular}{|c|c|c|c|c|c|c|c|c|c|c|}
\hline Ocean Uses & $\begin{array}{l}\text { Climate } \\
\text { regulation }\end{array}$ & $\begin{array}{l}\text { Flood control/ } \\
\text { shoreline } \\
\text { protection }\end{array}$ & $\begin{array}{l}\text { Nutrient } \\
\text { regulation }\end{array}$ & $\begin{array}{l}\text { Waste } \\
\text { treatment/ } \\
\text { control }\end{array}$ & $\begin{array}{c}\text { Nursery/ha } \\
\text { bitats }\end{array}$ & Fisheries & Biodiversity & Recreation & Aesthetic & $\begin{array}{l}\text { Scientific } \\
\text { research/ } \\
\text { education }\end{array}$ \\
\hline Land reclamation & 1.00 & 1.00 & 1.00 & 1.00 & 1.00 & 1.00 & 1.00 & 1.00 & 1.00 & 1.00 \\
\hline Coastal aquaculture* & 0.00 & 0.08 & 0.05 & 0.25 & 0.08 & 0.05 & 0.08 & 0.15 & 0.12 & 0.08 \\
\hline Offshore aquaculture & 0.00 & 0.00 & 0.00 & 0.20 & 0.08 & 0.03 & 0.08 & 0.12 & 0.05 & 0.03 \\
\hline $\begin{array}{l}\text { Impermeable } \\
\text { structure** }\end{array}$ & 0.35 & 0.24 & 0.53 & 0.52 & 0.61 & 0.53 & 0.53 & 0.30 & 0.25 & 0.19 \\
\hline Sea bridge & 0.00 & 0.09 & 0.00 & 0.00 & 0.25 & 0.22 & 0.35 & 0.12 & 0.08 & 0.16 \\
\hline Permeable structure*** & 0.09 & 0.09 & 0.00 & 0.00 & 0.28 & 0.24 & 0.39 & 0.16 & 0.12 & 0.16 \\
\hline Harbor/anchorage & 0.00 & 0.18 & 0.00 & 0.00 & 0.53 & 0.53 & 0.44 & 0.26 & 0.09 & 0.25 \\
\hline Shipping channel & 0.00 & 0.00 & 0.00 & 0.00 & 0.41 & 0.40 & 0.34 & 0.26 & 0.09 & 0.16 \\
\hline Seaside resorts & 0.06 & 0.00 & 0.10 & 0.26 & 0.41 & 0.35 & 0.20 & 0.00 & 0.00 & 0.00 \\
\hline Subsea pipeline & 0.00 & 0.00 & 0.00 & 0.00 & 0.08 & 0.05 & 0.18 & 0.05 & 0.01 & 0.10 \\
\hline Mining & 0.12 & 0.37 & 0.25 & 0.41 & 0.75 & 0.65 & 0.53 & 0.53 & 0.53 & 0.35 \\
\hline Intake/ outfall & 0.13 & 0.13 & 0.26 & 0.33 & 0.46 & 0.23 & 0.26 & 0.15 & 0.00 & 0.12 \\
\hline Sewage discharge & 0.00 & 0.00 & 0.00 & 0.00 & 0.36 & 0.38 & 0.32 & 0.00 & 0.00 & 0.21 \\
\hline Offshore dumping & 0.18 & 0.01 & 0.00 & 0.00 & 0.63 & 0.54 & 0.49 & 0.53 & 0.00 & 0.30 \\
\hline
\end{tabular}

601

Notes: $0=$ No damage, $1=$ Destruction.

*Aquaculture by enclosing the sea.

**Breakwater, jetty, pier, etc.

$* * *$ Dock and house on pilings. 
606

Table 7.MEDC Standard for Sea Area Use in Xiamen

\begin{tabular}{|c|c|c|c|c|c|c|c|c|c|c|c|c|c|c|c|}
\hline $\begin{array}{c}\text { Sea } \\
\text { Areas }\end{array}$ & $\begin{array}{c}\text { Eco- } \\
\text { zones }\end{array}$ & $\begin{array}{l}\text { Land } \\
\text { reclama- } \\
\text { tion* }\end{array}$ & $\begin{array}{l}\text { Coastal } \\
\text { aquacul- } \\
\text { ture }\end{array}$ & $\begin{array}{l}\text { Offshore } \\
\text { aquacul- } \\
\text { ture }\end{array}$ & $\begin{array}{l}\text { Imperme- } \\
\text { able struc- } \\
\text { ture** }\end{array}$ & $\begin{array}{c}\text { Sea } \\
\text { bridge } \\
* *\end{array}$ & $\begin{array}{c}\text { Permeable } \\
\text { struc- } \\
\text { ture** }\end{array}$ & $\begin{array}{c}\text { Harbor/ } \\
\text { anchorage }\end{array}$ & $\begin{array}{l}\text { Shipping } \\
\text { channel }\end{array}$ & $\begin{array}{c}\text { Seaside } \\
\text { resort }\end{array}$ & $\begin{array}{l}\text { Subsea } \\
\text { pipeline }\end{array}$ & Mining & $\begin{array}{c}\text { Intake/o } \\
\text { utfall }\end{array}$ & $\begin{array}{c}\text { Sewage } \\
\text { discharge }\end{array}$ & $\begin{array}{l}\text { Offshore } \\
\text { dumping }\end{array}$ \\
\hline \multirow{8}{*}{$\begin{array}{c}\text { Western } \\
\text { Sea }\end{array}$} & WS1 & 470 & 0.85 & 0.61 & 141 & 54 & 61 & 2.73 & 2.04 & 1.75 & 0.70 & 4.73 & 2.45 & 1.68 & 3.02 \\
\hline & WS2 & 384 & 0.71 & 0.51 & 115 & 41 & 47 & 2.05 & 1.58 & 1.39 & 0.53 & 3.78 & 1.96 & 1.26 & 2.34 \\
\hline & WS3 & 426 & 0.79 & 0.55 & 126 & 45 & 51 & 2.33 & 1.73 & 1.55 & 0.57 & 4.25 & 2.23 & 1.39 & 2.59 \\
\hline & WS4 & 326 & 0.64 & 0.47 & 101 & 32 & 37 & 1.75 & 1.40 & 1.34 & 0.39 & 3.41 & 1.84 & 1.08 & 2.05 \\
\hline & WS5 & 426 & 0.79 & 0.55 & 126 & 45 & 51 & 2.33 & 1.73 & 1.55 & 0.57 & 4.25 & 2.23 & 1.39 & 2.59 \\
\hline & WS6 & 434 & 0.79 & 0.55 & 129 & 46 & 53 & 2.41 & 1.80 & 1.61 & 0.58 & 4.36 & 2.27 & 1.45 & 2.67 \\
\hline & WS7 & 377 & 0.71 & 0.47 & 110 & 34 & 39 & 1.89 & 1.40 & 1.35 & 0.39 & 3.73 & 1.97 & 1.08 & 2.10 \\
\hline & Others & 354 & 0.68 & 0.51 & 110 & 40 & 45 & 1.98 & 1.57 & 1.38 & 0.53 & 3.62 & 1.89 & 1.25 & 2.28 \\
\hline \multirow{3}{*}{$\begin{array}{c}\text { Estuary } \\
\text { Sea }\end{array}$} & ET1 & 441 & 0.81 & 0.56 & 130 & 49 & 55 & 2.44 & 1.81 & 1.56 & 0.63 & 4.35 & 2.24 & 1.47 & 2.69 \\
\hline & ET2 & 421 & 0.78 & 0.53 & 124 & 44 & 51 & 2.27 & 1.68 & 1.48 & 0.56 & 4.14 & 2.14 & 1.35 & 2.50 \\
\hline & others & 342 & 0.67 & 0.49 & 105 & 38 & 43 & 1.83 & 1.45 & 1.24 & 0.52 & 3.41 & 1.75 & 1.15 & 2.11 \\
\hline \multirow{6}{*}{$\begin{array}{c}\text { Tongan } \\
\text { Sea }\end{array}$} & TA1 & 412 & 0.76 & 0.52 & 121 & 41 & 47 & 2.21 & 1.64 & 1.51 & 0.50 & 4.11 & 2.15 & 1.30 & 2.45 \\
\hline & TA2 & 463 & 0.84 & 0.60 & 138 & 53 & 60 & 2.66 & 1.99 & 1.71 & 0.69 & 4.66 & 2.42 & 1.63 & 2.96 \\
\hline & TA3 & 334 & 0.66 & 0.48 & 103 & 35 & 40 & 1.79 & 1.42 & 1.28 & 0.46 & 3.39 & 1.78 & 1.11 & 2.07 \\
\hline & TA4 & 350 & 0.68 & 0.48 & 105 & 36 & 41 & 1.84 & 1.42 & 1.28 & 0.46 & 3.51 & 1.82 & 1.11 & 2.07 \\
\hline & TA5 & 374 & 0.72 & 0.48 & 109 & 37 & 42 & 1.93 & 1.42 & 1.28 & 0.46 & 3.68 & 1.88 & 1.11 & 2.08 \\
\hline & Others & 332 & 0.65 & 0.47 & 102 & 35 & 40 & 1.77 & 1.41 & 1.28 & 0.45 & 3.37 & 1.77 & 1.10 & 2.05 \\
\hline \multirow{3}{*}{$\begin{array}{l}\text { South- } \\
\text { ernSea }\end{array}$} & SS1 & 596 & 1.26 & 0.92 & 152 & 57 & 68 & 3.29 & 2.73 & 1.33 & 0.72 & 6.12 & 2.60 & 1.28 & 4.74 \\
\hline & $\mathrm{SS} 2$ & 572 & 1.22 & 0.92 & 148 & 56 & 67 & 3.21 & 2.73 & 1.33 & 0.72 & 5.94 & 2.53 & 1.28 & 4.73 \\
\hline & Others & 357 & 0.69 & 0.51 & 112 & 39 & 44 & 2.03 & 1.61 & 1.47 & 0.49 & 3.74 & 2.00 & 1.28 & 2.36 \\
\hline Eastern & ES1 & 628 & 1.31 & 0.97 & 163 & 63 & 74 & 3.60 & 2.97 & 1.55 & 0.78 & 6.55 & 2.86 & 1.49 & 5.11 \\
\hline
\end{tabular}




\begin{tabular}{|c|c|c|c|c|c|c|c|c|c|c|c|c|c|c|c|}
\hline \multirow[t]{3}{*}{ Sea } & ES2 & 386 & 0.62 & 0.44 & 118 & 45 & 51 & 2.40 & 1.85 & 1.55 & 0.56 & 4.07 & 2.13 & 1.49 & 2.78 \\
\hline & ES3 & 615 & 1.29 & 1.01 & 166 & 66 & 79 & 3.70 & 3.16 & 1.67 & 0.88 & 6.55 & 2.90 & 1.66 & 5.37 \\
\hline & others & 389 & 0.74 & 0.56 & 123 & 44 & 50 & 2.34 & 1.85 & 1.70 & 0.56 & 4.18 & 2.26 & 1.49 & 2.73 \\
\hline \multirow{3}{*}{$\begin{array}{c}\text { Dadeng } \\
\text { Sea }\end{array}$} & DD1 & 348 & 0.68 & 0.50 & 107 & 39 & 44 & 1.88 & 1.49 & 1.27 & 0.54 & 3.48 & 1.79 & 1.19 & 2.17 \\
\hline & DD2 & 392 & 0.73 & 0.51 & 107 & 40 & 47 & 2.08 & 1.69 & 1.02 & 0.52 & 3.87 & 1.75 & 1.02 & 2.74 \\
\hline & others & 321 & 0.63 & 0.45 & 98 & 33 & 38 & 1.65 & 1.31 & 1.16 & 0.44 & 3.19 & 1.65 & 1.02 & 1.90 \\
\hline
\end{tabular}

607

608 Notes: Units are in RMB yuan $/ \mathrm{m}^{2}$.yr, except for four uses (land reclamation, impermeable structure, sea bridge, and permeable structure).

609 RMB 1 yuan $=0.16$ US Dollar. .

$610 *$ Lump-sum payment calculated as the annual value divided by discount rate $(r=2 \%)$. Unit is in $\mathrm{RMB} \mathrm{yuan} / \mathrm{m}^{2}$.

$611 * *$ Lump-sum payment calculated using Equation (2) with $r=2 \%$ and $n=50$ years. Unit is in RMB yuan $/ \mathrm{m}^{2}$. 